\title{
Impact of Selected Fruits Production on Pakistani Exports
}

\author{
Ashiq Hussain ${ }^{1}$, Muhammad Ajmair ${ }^{2}$ \\ ${ }^{1}$ Director, Mian Muhammad Bukhash Public Library, Mirpur AJK, Pakistan \\ ${ }^{2}$ Assistant Professor, Mirpur University of Science and Technology, Mirpur AJK, Pakisatn
}

\begin{abstract}
The purpose of this research is to analyze the impact of fruit production of selected fruits; banana, citrus, mango, apricot and almond on the export. Unit root test, simple OLS methods were applied on the time series data of Pakistan for the period of 19922010 to analyze the impact of fruit production on exports. The results of OLS show that there is positive role of apple production on export. Farmers should be motivated to produce apple to export.
\end{abstract}

Keywords: Fruit production, Exports, OLS, Unit root test, Motivation

\section{Introduction}

Pakistan is basically an agro-based economy in a way that the biggest chunk of economic resources is generated by agriculture sector. Agriculture sector does not only provide direct income to population but it also supports industrial sector by providing raw material to it. Butt et al. (2010) described that total population of Pakistan reached to 163.76 million in 2008-09, majority of which depends upon agriculture which remains the dominant sector in its capacity of labour absorption and in employment creation for $44 \%$ of population. Pakistan Ministry of Finance (2004) in its overview of Pakistan's Economy reported that after much diversification in agriculture sector, it still remains the largest sector of economy which contributes $23.3 \%$ to GDP by engaging $42.1 \%$ of the labour force in the year 2004 . Moreover it brings largest share of foreign exchange earnings by acting as a base for major industries like textile and sugar. It not only provides raw material to industrial sector but also serve as a market for its products and is therefore involved in round-about development of the country. Baig and Khan (2006) reported the fact that $67.5 \%$ of population living in rural areas is either directly or indirectly dependent upon agriculture for economic gains. Agriculture also has numerous linkages with other non-farm rural activities which enable the population to generate employment and earn income in adjoining areas.

Pakistan has a rich and vast natural resource base, covering various ecological and climatic zones; hence the country has great potential for producing all types of food commodities. Agriculture has an important direct and indirect role in generating economic growth. The importance of agriculture to the economy is seen in three ways: first, it provides food to consumers and fibres for domestic industry; second, it is a source of scarce foreign exchange earnings; and third, it provides a market for in dustrial goods.

The total geographical area of Pakistan is 79.6 million hectares. About 27 percent of the area is currently under cultivation. Of this area, 80 percent is irrigated. In this regard, Pakistan has one of the highest proportions of irrigated cropped area in the world. The cultivable waste lands offering good possibilities of crop production amount to 8.9 million hectares. Growth in cropped area is very impressive: from 11.6 million hectares in 1947 to 22.6 million hectares in 1997. Agriculture is an important sector, providing food to the fast-growing population of the country. According the 1998 census, the total population of Pakistan is 130 million. With a population growth rate of 2.6 percent there is a net addition of 3.4 million people each year. In 1947 the population of Pakistan was 32.5 million; in 50 years it has increased fourfold Agriculture contributes about 24 percent of the gross domestic product (GDP) and employs 47 percent of the national employed labour force. The contribution of the agricultural sector to the GDP has declined gradually since Pakistan came into existence, from over 50 percent in 1949-50 to about 24 percent in 1996-97. Agriculture still remains the major sector of the GDP composition. A major part of the economy depends on farming through production, processing and distribution of major agricultural commodities. The average annual growth rates in the agricultural sector during the 1960s, 1970s and 1980s were 5.07, 2.37 and 5.4 percent, respectively. With the announcement of a new agriculture package by the government in April 1997, the growth rate during 1997/98 has improved to 5.9 percent. Pakistan's fruit exports went up $33 \mathrm{pc}$ in dollar terms in the 5 months of the current fiscal year as compared to last fiscal year. Figures released by the FBS revealed shipment of 218,203 tones of fruits $(\$ 143.4 \mathrm{~m})$ in July-Nov 2013-2014 as compared to 191,739 tones $(\$ 103 \mathrm{~m})$ in same period last fiscal year.. Boost in mango, exports played a positive impact on overall growth in fruit. Over 190,000 tones of mango were exported to Europe, Canada, Middle East, Far East, Japan and South Korea this season. Other fruits included apple, cheeko. Waheed said that overall exports of fruits can improve when the export of kinnow and mango resume to Iran. Pakistan is facing a ban on these items by Iran for the last three years.

Pakistan used to ship 25,000-30,000 tones of mango to Iran, fetching around $\$ 15 \mathrm{~m}$ per year. Similarly, export of around 80,000-90,000 tones of keno to Iran, fetching $\$ 40 \mathrm{~m}$. Pakistan, though a major citrus producer, is still lagging behind in modern techniques when it comes to enhancing the value of citrus exports. Only $10 \%$ of total production is exported, due to which citrus producers face severe financial constraints as it entails selling the produce locally; at lower 


\section{International Journal of Science and Research (IJSR) \\ ISSN (Online): 2319-7064}

Index Copernicus Value (2013): 6.14 | Impact Factor (2015): 6.391

prices. The year witnessed a generally good crop: production of kinnows went up to 2.4 million tons and the export target was fixed at 300,000 tons; but the loss of Iran's lucrative market and delays in consignments due to stringent commodity checks by customs authorities were major problems from the exporters' view point. Furthermore, Sri Lanka imposed a special commodity levy on imports of fruit and vegetables which annoyed local exporters at a time when the citrus export season was underway.

Mango exports are an important source of valuable foreign earnings for Pakistan. Exports increased from 1.16 thousand tons in 1975-76 to 105.21 thousand tons in 2006-07. The last five years witnessed massive increase in the mango exports from Pakistan. An increase in mango exports from Pakistan is generally attributed to increased access to traditional markets through improved shipping facilities, increasing number of Pakistani immigrants and policy of the government (PHDEB, 2005). Despite an increase in its exports, share of mango exports remains about 6 percent of the total mango production which is lower than other leading mango exporting countries like Mexico and Brazil contributing 14 percent and 12 percent respectively . Export of mango from Pakistan is highly concentrated in few markets. Major markets for Pakistani mango include United Arab Emirates and Saudi Arabia where expatriate Pakistanis and Indians, constitute major segment of customers base. Increased shipping facilities at cheaper rates, relatively flexible and less stringent food safety requirements are some other factors contributing major share of exports to these markets. For the year 2006-07, 46 percent of mango was exported to UAE alone whereas Saudi Arabia, Oman, Kuwait, and Bahrain accounted for 17.61 percent, 12.79 percent, 1.55 percent and 1.22 percent respectively of the total exports of mango from Pakistan. Almost 76 percent of Pakistani mango was exported to three markets (UAE, Saudi Arabia and Oman). United Kingdom is the biggest market in Europe constituting about 11.46 percent whereas France and Germany share about 1.48 percent and 1.22 percent respectively of total exports from Pakistan . Pakistan is the sixth largest exporter of mangoes in the world. In 2007-08, Pakistan exported 61,632 tons of mangoes; while in 200607 , export figure was 105,210 tons. Pakistan's compounded annual growth rate of mango exports during the period 2000-07 remained as 3.2\%, which was much lower than the export market growth rate of $9.0 \%$ during the same time period. This indicates that Pakistan has not been able to tap the growing potential of fresh mango export market. Two main mango varieties exported from Pakistan are Sindhri and Chaunsa; Sindhri being the main variety of Sindh.

Around 30 tonnes of apples are being exported on a daily basis to neighbouring countries. The apples are not produced in the province, but transported to Jalalabad from Kabul and central Maidan Wardak before being sent to Pakistan So far 1,300 tonnes of apples worth $\$ 250,000$ had been exported to the neighbouring country, with daily exports working out at 30 tonnes.

\subsection{Objectives of the Study}

To see the share of selected fruits production in total exports

\section{Literature Review}

Although there exists a lot of potential in exporting fruits from Pakistan yet this crop has attracted least interest of scholars as only few studies are available which estimated determinants of fruits export from Pakistan. However, in this section, an effort is made to review relevant literature.

Aujla, et al. (2007) investigated constraints hindering realization of true potential of Pakistan's fruit production and exports. The major share in returns from exports came from Middle Eastern and Far Eastern countries due to relatively high quantities exported to these regions. The inability to compete in the expensive markets of the world in horticultural products was because of non-availability of infrastructures like hi-tech labs for issuing various certificates on health and environmental safety, noncoincidence of Pakistan's fruits with the tastes and preferences of high-price markets, expensive refrigerated transport facility, costly good quality packing material, other inputs needed in processing and non-availability of credit on easy terms and conditions.

Haleem (2005) investigated export supply response of mango in Pakistan during last thirty years (1975-2004) using Johansen's cointegration technique. The estimated exports price elasticity for mango was 5.39 whereas domestic price elasticity was -6.73 and domestic production elasticity was 2.16 . The exchange rate elasticity remained 2.89 . Haleem et al. (2005) examined factors affecting export of citrus. These factors included domestic and export prices, national production, foreign exchange rate etc. Time series data for the period 1975-2004 were used for analysis employing the co-integration and error correction mechanism. The estimated export price elasticity was 1.48 while domestic price elasticity was -0.98 . Among non-price factors, the estimated elasticity for domestic production of citrus, exchange rate and GDP were $1.37,1.31$ and 0.35 respectively.

Hassan and Ibnouf (2005) identified competitive capacity determinants (relative prices, relative stability of production, and efficiency of export practices) for Egyptian exports of some fruits in the Saudi Arabian market using time series data for the period 1985-2000. Multiple linear regression equations were estimated for finding out relationship between dependent and explanatory variables. The results indicated that competitive capacity of Egyptian exports for these major fruits in the Saudi Arabian market could be increased by expanding the production of quality oranges and lemons, improving the efficiency of export processes, and reducing the costs of mango production while meeting product specifications and maintaining the relative stability of production.

Neef (2004) scanned behavior of exports of peers, apples and strawberries from Belgium by using time series data for a period 1975-2003. The findings of the study found that internal factors like production and per capita availability played important role in explaining variations in net exports, while external factors like prices and foreign exchange rates appeared to be less important. 


\section{International Journal of Science and Research (IJSR) \\ ISSN (Online): 2319-7064 \\ Index Copernicus Value (2013): 6.14 | Impact Factor (2015): 6.391}

Dr. Gayaneh, (2010) Fruits and vegetables have long been a nutritious and healthful part of the human diet because they are low in calories and fat, and are important sources of vitamins, minerals, and fibre. In addition, fruits are also high in phonetic compounds such as anthocyanins and flavanoids, which have been correlated with lower risks of chronic diseases. The challenge of the producer has always been to find ways to preserve food in a high quality state until it reaches the consumer. In Thane and Reddy (1997) point of view, some fruits and vegetables require peeling before processing, such as peaches, tomatoes and carrots. This process may be achieved with the use of hot water, hot sodium hydroxide solution or mechanical peelers. This process may remove some of the nutrients with the portions that are separated from the peeled products. Also, by exposing the flesh/phloem of the fruit/vegetable to the atmosphere, some carotene activity may be lost through oxidation.

According to Thane and Reddy (1997), the amount of arytenoids is also not affected by freezing, particularly rapid freezing. Deteriorative process occurs, although at a very low rate, during storage. This is desirable, of course, because of the high value placed on arytenoids as nutrients.

According to the Organizational high-level international review of research findings on fruit and vegetable consumption and cancer risk, coordinated by the WHO International Agency for Research on Cancer (IARC), concluded that eating fruit and vegetables may lower the risk of some cancers, particularly cancers of the gastrointestinal tract. IARC estimates that the preventable percentage of cancer due to low fruit and vegetable intake ranges from 5$12 \%$ for all cancers, and up to $20-30 \%$ for upper gastrointestinal tract cancers worldwide.

The importance of fruit and vegetable consumption for a healthy diet, and the need for the promotion of fruit and vegetable production and consumption, were reiterated. Several Member States reported low fruit and vegetable intake in their population, with some describing consumption barriers such as high price. The country representatives from the Region of the Americas and the South-East Asia Region explicitly identified increasing fruit and vegetable production and consumption as

Bonilla , 2004A national web survey was used to collected data from 253 households in the United States. Choice-based conjoint analysis was used to investigate which packaging and labelling attributes U.S. consumers consider important when choosing $100 \%$ fruit juices, and to estimate their willingness-to-pay. The attributes were packaging material, nutritional and health claims, presence of organic ingredients and whether the product was produced locally. Factor analysis, cluster analysis and a median split technique were used to identify market segments based on consumer preferences, behaviour, and lifestyles. Differences between the segments were analysed.

A conditional logit model was used to estimate relative of importance and willingness-to-pay for the different attributes. Results from the study show that consumers place positive values on, and are willing to pay a premium of
(\$1.04) for the Polyethylene Terephthalate (PET) bottle and (\$0.29) more for the no sugar added claim. Consumers with high environmental interests were more likely to pay a premium for a fruit juice with organic ingredients and a nutritional index on the label. High information seekers are willing to pay $(\$ 0.13)$ more for the nutritional index; compared to $(\$ 0.05)$ that low information seeker will pay. Younger people are willing to pay more for local products and more than double (\$1.41) of what older people will pay (\$0.67) for a PET bottle.

According to Abbot, "With an increasing emphasis on health, nutrition and environment, changing life styles and higher incomes, the U.S. market offers several opportunities for new products. Today's trends for healthy eating habits and "ready to eat" products has increased consumer demand for more detailed and accessible information, primarily on food packaging and labels. Consumers like to know the ingredients and the features related to food safety (Abbott, 1997). Although product attributes such as quality and price are extremely important to consumers, packaging and labelling play a fundamental role on consumer's intention to purchase. These factors are important because they represent the first line of contact between the consumer and the product".

In Johnson point of view, over the last decade, there has been a growing U.S. trade deficit in fresh and processed fruits and vegetables. Although U.S. fruit and vegetable exports totaled more than $\$ 10$ billion in 2009, U.S. imports of fruits and vegetables were nearly $\$ 16$ billion, resulting in a gap between imports and exports of almost $\$ 6$ billion. This trade deficit has widened over time-despite the fact that U.S. fruit and vegetable exports have continued to rise each year-because growth in imports has greatly outpaced export growth. As a result, the United States has gone from being a net exporter of fresh and processed fruits and vegetables in the early 1970 s to being a net importer of fruits and vegetables today. A number of factors shaping current competitive market conditions worldwide, and global trade in fruits and vegetables in particular, partially explain the rising fruit and vegetable trade deficit. These include:

- A relatively open domestic import regime and lower average import tariffs in the United States, with products from most leading suppliers entering the U.S. duty-free or at preferential duty rates;

- Increased competition from low-cost or governmentsubsidized production;

- Continued non-tariff trade barriers to U.S. exports in some countries, such as import and inspection requirements, technical product standards, and sanitary and

According to HUANG, "International trade in fruits and vegetables has expanded at a higher rate than trade in other agricultural commodities, particularly since the 1980s. Not only has world trade in fruits and vegetables gained prominence, but the variety of commodities has expanded. Over the years, three regions - the European Union (EU), the North American Free Trade Agreement (NAFTA) area, and Asia (East, Southeast, and South) - have remained as both the major destinations and sources of supply. A substantial share of their trade is interregional, particularly that of the EU. 


\section{International Journal of Science and Research (IJSR) \\ ISSN (Online): 2319-7064 \\ Index Copernicus Value (2013): 6.14 | Impact Factor (2015): 6.391}

Visser , 2012 Horticulture value chains in South Africa are undergoing a process of rapid transformation. The sector is significant in the generation of agricultural GDP, employment and exports. European supermarkets have long been an important destination for fruit. Supermarkets source through coordinated value chains, with stringent requirements and have driven the rise of private standards. These improve quality but increase the commercial pressures and costs for growers.

Agricultural work has low esteem, and the sector faces a serious shortage of skilled labour despite rural unemployment. Current public and private provision of training is insufficiently resourced to generate an adequate pool of skilled labour. Growers and workers need better returns to ensure the resilience of quality horticulture value chains to supermarkets. Public and private policy needs to enhance the skills and empowerment of workers, and support social provision to increase the appeal of working in horticulture.

Global wise 2012 Washington's apple industry is a major contributor of income, employment and tax revenues to the state's economy. The industry boosted the Washington economy by an estimated $\$ 7.02$ billion in direct, indirect and induced economic activity in 2010-2011. This sector also accounted for an estimated 59,650 jobs and total annual employee compensation of $\$ 1.95$ billion. Business owners' income in the state totaled $\$ 837.6$ million as a result of the apple industry economic activity. The tax revenue contributions of the industry were also very sizable.

At the state and local level, the total tax revenues generated by the Washington apple industry were $\$ 188.7$ million. Federal tax revenues contributions were estimated to be $\$ 300.3$ million.

Apple exports are a key element of future economic prosperity for the industry and for the prosperity of the Washington state economy. About one third of total fresh apple production is exported. Growers have been expanding high density tree plantings and adopting new varieties while packers have been investing in new packing and storage facilities. If exports falter, grower income is at risk. This analysis shows that if 5,000 carlots of fresh apples (a carlot is 1,000 40 pound boxes) destined for export were instead added to domestic markets, the income loss to growers would be about $\$ 55.17$ million. This in turn would negatively impact the Washington economy with a decline of 925 jobs, loss of employee compensation of $\$ 37.0$ million, loss of state and local tax revenue of $\$ 7.34$ million and loss of federal tax revenue of $\$ 9.48$ million.

This analysis was based on the best available data and information for the marketing year September 2010 to August 2011. Effort was made to separate apple production, packing, processing and marketing and research activities from all other tree fruit crops. However, apples account for about 80 percent of tree fruit production in the state and most growers and packers also grow or pack sweet cherries, pears or other tree fruits. This study does not account for the economic impacts of these closely related fruit sectors, but it should be pointed out that these tree fruits are synergistic and highly integrated with the dominant apple business.

(FE van Dyk, 2004) This paper gives an overview of a study that was done on the logistics infrastructure used by the South African fruit industry. Given the increasing production and export volumes, development of new markets and the shortage of logistics infrastructure capacity during peak seasons, the SA fruit industry identified the need to investigate the optimal usage of existing infrastructure on a national level and to make recommendations with regards to the development of additional infrastructure. Some background on the SA fresh fruit industry and its export supply chain are provided. This is followed by a description of the four project phases and their deliverables. The paper is concluded with the key findings of the study.

(Swenson, 2010) This research project investigated the regional potential of increased fruit and vegetable production in southwest Iowa. The study region is composed of 10 counties: Adair, Adams, Audubon, Cass, Guthrie, Harrison, Mills, Montgomery, Pottawattamie, and Shelby. This area includes some of Iowa's most rural areas, yet it also is strongly influenced by the metropolitan reach of Omaha and Council Bluffs to the west and Des Moines on the east. Iowa only produces a small fraction of its annual consumption of fresh fruits and vegetables and must import these agricultural commodities from other areas to meet our needs. One way in which rural economies can grow is to replace imports with local production, or through import substitution. The other much more common manner in which rural economies can increase local incomes is by increasing the volume or the kinds of commodities that they export. Anything that is sold beyond the region's boundaries constitutes an export sale for the producing area, whether it goes to other parts of the state, or to meet the heightened demand shown in the eastern and western bordering metropolitan areas. This research investigated the potential value of import substitution and export sales of fruit and vegetable production in southwest Iowa. This research was supported in its entirety by the Leopold Centre for Sustainable Agriculture at Iowa State University.

(Godwin. M. Ahimbisibwe, 2013) The purpose of this study was to investigate the impact of export market orientation, innovation on the export performance of fruit exporting firms in Uganda. The study was prompted by the fact that Uganda's fruit exports were growing marginally when compared to other fruit exporting countries in the COMESA region. And it wasn't clear whether this trend could be attributed to low levels of export market orientation and innovativeness that seemed to characterize most of the fruit exporting firms in Uganda, besides research on export market orientation, innovation and export performance is disappointingly scarce in Uganda. Therefore, a quantitative cross sectional research design was adopted to undertake the study. A field study using simple random sampling was used to select a sample of 56 firms whose 3 top executives were key informants. Correlation analysis was carried out on the study and the findings revealed a significant positive between innovation, market orientation and export performance of fruit exporting firms in Uganda which 


\section{International Journal of Science and Research (IJSR) \\ ISSN (Online): 2319-7064 \\ Index Copernicus Value (2013): 6.14 | Impact Factor (2015): 6.391}

confirmed earlier submissions by previous researchers. However when a regression model was conducted, it was observed that innovation was a significant predictor of export performance while export market orientation wasn't. It was therefore recommended that fruit exporting firms in Uganda should focus more on innovation if they are to enhance their export performance.

(Ricardo Hausmann, 2007) According to Beneficiation, moving downstream, and promoting greater value added in natural resources are very common policy initiatives to stimulate new export sectors in developing countries, largely based on the premise that this is a natural and logical path for structural transformation. But upon closer examination, we find that very few countries that export raw materials also export their processed forms, or transition to greater processing. The quantitative analysis finds that broad factor intensities do a much better job of identifying patterns of production and structural transformation than forward linkages, which have an insignificant impact despite the fact that our data is biased against finding significant effects of factor intensities and towards finding significant effects of forward linkages. Moreover, the explanatory power of forward linkages is even smaller in sectors with high transport costs, and in sectors classified as primary products or raw materials, which are the most common targets of such policies. Finally, the results are the same even when only considering developed countries, meaning that colonial? legacy inhibiting transitions to natural resource processing are not to blame. These results suggest that policies to promote greater downstream processing as an export promotion policy is misguided. Structural transformation favours sectors with similar technological requirements, factor intensities, and other requisite capabilities, not products connected in production chains. There is no reason for countries like South Africa to focus attention on beneficiation at the expense of policies that would allow other export sectors to emerge. This makes no sense conceptually, and is completely inconsistent with international experience. Quite simply, beneficiation is a bad policy paradigm.

(EMMANUEL, 2002) This study was prompted after observing the sporadic nature of Uganda's fruit exports in the last 8 years. This fact was strengthened by the overall fall in exports in Uganda to other neighboring countries and the dismal engagement in global trade by Sub-Saharan Africa countries despite the advent of globalizations and regional economic integration and corporation. The objectives of this study therefore were to: Determine the relationship between firm characteristics and export marketing strategy, determine the relationship between firm characteristics and export performance, determine the relationship between export marketing strategy and export performance, and determine the relationship between management attitudes and export marketing strategy. To achieve the above objectives, a quantitative correlation research design was used to execute the study. A sample of 31 firms was taken after stratifying the population and then sampling purposively. Data was collected using a well pretested questionnaire and analyzed using statistical package for social scientists. The study demonstrated that indeed firm characteristics, management attitudes and export marketing strategy are key determinants of export performance among fruit exporters in Uganda. This was confirmed by R2 of $45.3 \%$. Management of fruit exporting firms should $\mathrm{d}$ therefore consider putting in place strategies to address aspects of firm characteristics, management attitudes, export marketing strategy and export performance in order to win in the international market.

\section{Methodology}

\subsection{Methodology}

Simple OLS methods are used to check the relationship between dependent variable (Fruit Exports) and independent variable (citrus, mangoes, apple, apricot and almond)

In statistics, linear regression is an approach to modeling the relationship between a scalar dependent variable and one or more explanatory variables denoted by $\mathrm{X}$. The model stipulates the impact of fruit production on Pakistani exports.

exts $_{t}=\beta_{0}+\beta_{1}$ cit $_{t}+\beta_{2}$ man $_{t}+\beta_{3}$ ban $_{t}$

$+\beta_{4} a p p_{t}+\beta_{5} a p r_{t}+\beta_{6} a l m+\varepsilon_{t}$

Where exts stand for exports of fruits, cit is production of citrus, man is mangoes, app is apple, apr is apricot and alm is used for almond.

\subsection{Analysis and discussions}

This section includes descriptive as well as quantitative analysis and results of these analyses are discussed in this section.

\subsection{Quantitative Analysis}

For analysis of data one method is used in this study: that is regression. Initially regression is used to check the impact of different independent variables on the dependent variable and also to test significance of this impact.

\section{Results and Discussion}

\subsection{Analysis of Results of Unit Root}

This paper is an attempt to investigate the relationship between production of selected fruits and their exports. Secondary data of 19 years from 1992 to 2010 is used for this purpose. The first step in the empirical analysis involves testing the time series characteristics of the data series using ADF tests. All the variables used in this study are stationary in their level. Regarding the hypothesis of the study it is concluded that the entire Hypothesis has not positive impact on exports. Because of Multiple linear regression exports has not complete positive relation with the production of selected fruits. 


\section{International Journal of Science and Research (IJSR) \\ ISSN (Online): 2319-7064}

Index Copernicus Value (2013): 6.14 | Impact Factor (2015): 6.391

\section{ADF test of result of agri sector \& export}

\begin{tabular}{|c|c|c|c|}
\hline S\# & Variables & Intercept and trend & Order of integration \\
\hline 1 & Extst & -2.6608 & $1(0)$ \\
& & -0.7172 & \\
\hline 2 & Cit & $-2.6829 * * *$ & $3(0)$ \\
& & 0.144 & \\
\hline 3 & Man & $-2.6608^{* * *}$ & $1(0)$ \\
& & 0.144 & $1(0)$ \\
\hline 4 & App & $-2.6608^{* * *}$ & -2.028 \\
& & $-2.6608^{* * *}$ & $1(0)$ \\
\hline 5 & Apr & -1.870 & $1(0)$ \\
& & $-2.6608^{* * *}$ & \\
\hline 6 & Alm & -0.8593 & \\
& & \multicolumn{2}{|}{}
\end{tabular}

NOTE: * denote the rejection of the null hypothesis at $1 \%$ level of significance, $* *$ denotes the rejection of the null hypothesis at $5 \%$ level of significance, *** denotes the rejection of the null hypothesis at $10 \%$ level of significance, Legged: EXPT stands for fruits exports of Pakistan in tons. Cit stands for citrus, Man stands for mango, App stands for apple, Apr stands for apricot and Alm stands for almond.

\section{Multiple Linear Regression Output}

\begin{tabular}{|c|c|c|c|c|}
\hline Variable & Coefficient & Std. Error & t-Statistic & Prob. \\
\hline $\mathrm{C}$ & 1.6693 & 1.267177 & 1.31737 & 0.212 \\
\hline LOGCIT & -0.4358 & 0.402495 & -1.0828 & 0.300 \\
\hline LOGMAN & 0.3360 & 0.309367 & 1.08628 & 0.298 \\
\hline LOGAPP & 1.3149 & 0.419622 & 3.13376 & 0.008 \\
\hline LOGBAN & 0.0357 & 0.147446 & 0.24237 & 0.812 \\
\hline LOGAPR & 0.0344 & 0.311032 & 0.11089 & 0.913 \\
\hline LOGALM & -1.62776 & 0.415764 & -3.9151 & 0.002 \\
\hline R-squared & 0.917988 & \multicolumn{2}{|c|}{ Mean dependent var } & 2.350543 \\
\hline $\begin{array}{l}\text { Adjusted R- } \\
\text { squared }\end{array}$ & 0.876982 & \multicolumn{2}{|c|}{ S.D. dependent var } & 0.205539 \\
\hline S.E. of regression & 0.072091 & \multicolumn{2}{|c|}{ Akaik info criterion } & -2.14 \\
\hline Sum squared resid & 0.062365 & \multicolumn{2}{|c|}{ Schwarz criterion } & -1.79 \\
\hline Log likelihood & 27.37253 & \multicolumn{2}{|c|}{ F-statistic } & 22.38 \\
\hline $\begin{array}{c}\text { Durbin-Watson } \\
\text { stat }\end{array}$ & 2.160240 & \multicolumn{2}{|c|}{ Prob(F-statistic) } & 0.000 \\
\hline
\end{tabular}

From the regression output explains that there is negative and insignificant relationship between exports of selected fruits and citrus production. Production of almond is also affecting fruits exports negatively and significantly. But when we observe the relationship of production of mangoes, apple, banana and apricot with fruit exports, we come to know that all are affecting positively and insignificantly except apple that is affecting significantly.

\section{Conclusions}

Besides description of the impact of agricultural fruits on export, this paper provides insights into the possible inter relation and inter- dependencies between the export and agricultural fruits, citrus, mango, apple, banana, almond and apricot during the period 1992-2010. According to the empirical results, a change in the agricultural fruits output leads to a more than proportional change in exports in the long run. An important policy implication of this study is that an expansion in agricultural fruits in Pakistan can provide important revenue for the economic growth. It is important for additional measures to improve the fruit production and the exports. On the basis of findings it is recommended that Government of Pakistan should give incentives to the farmers producing apples.

\section{References}

[1] Abbot, R. (1997). Food and nutrition information: a study of sources, uses and understanding. British Food Journal 99 (2): 43-49.

[2] Abid, M. Sami Khan (1980) Marketing Infra-structure, Margins and Seasonal Price Variation of Selected Agricultural Commodities in Sindh Province of Pakistan.

[3] Anon( 2007) Food and Agriculture Organization of the United Nations (FAO). The Lahore Journal of Economics 14 : 2 (Winter 2009): pp. 125-133

[4] Abbas.M.,(2013) Effect of trade deficit on the economy of Pakistan Institute of Interdisciplinary Business research;4

[5] Albisu, L.M. (1995). Tree Nuts Economic Outlook in The Mediterranean Area: The Selection of Main Research Area. Documento de Trabajo 95/2. Servicio de Investigacion Agraria, Unidad de Economíay Sociología Agrarias, Zaragoza.

[6] Bonilla, T. (2004). analysis of consumer preferences toward $100 \%$ fruit juice packages and labels.

[7] Dr. Gayaneh, D. J. (2010). Nutritional Comparison of Frozen and Non-Frozen Fruits and Vegetables. The Food Processing Center University of Nebraska-Lincoln

[8] Emmanuel, B. (2002). firm characterisitcs, management attitudes, and export performance in fruit sector. badaza emmanuel 2002/HDI0/1699/U .

[9] FE van Dyk, E. M. (2004). An analysis of the South African fruit logistics infrastructure. ORiON ISSN 0529-191-X c ${ }^{\circ} 2004$.

[10] Globalwise Inc., V. W. (2012). The Washington Apple Industry. Globalwise .

[11] Godwin. M. Ahimbisibwe, J. .. (2013). export market orientation, innovation and performance of fruit exporting firms in uganda. european Scientific Journal February 2013 edition vol.9, No.4 ISSN: $1857-7881$ (Print) e - ISSN 1857- 7431 .

[12] http://www.nation.com.pk/business/24-Dec2013/pakistan-s-exports-of-fruits-vegetables-rise

[13] http://www.dawn.com/news/744721/outlook-forbanana-production

[14] http://www.dawn.com/news/2011/outlook of apple production

[15] Huang, S. W. (2006). Global Trade Patterns in Fruits and Vegetables. United States Department of Agriculture .

[16] Johnson, R. (2012). The U.S. Trade Situation for Fruit and Vegetable Products . Congressional Research Service .

[17] Khan, D. A. (1994) Problems and Prospects of Horticulture in Pakistan. Proceedings of the First International Horticulture Seminar. Islamabad: Pakistan Agriculture Research Council.

[18] Khushk.A.M.,D.Smith \&Laurence . A preliminary y Analysis of marketing Mango In Sindh Province, Pakistan.National Agricultural research Centre.

\section{Volume 5 Issue 6, June 2016 www.ijsr.net}




\section{International Journal of Science and Research (IJSR) \\ ISSN (Online): 2319-7064}

Index Copernicus Value (2013): 6.14 | Impact Factor (2015): 6.391

[19] Mohy-ud-din, Q. (1991) Improving Marketing System of Citrus Fruit in the Punjab Province. Pakistan Agricultural Development Review 1:2 35-44.

[20] Memon, R. A. (1978) Marketing Infra-structure, Margins and Seasonal Price Variation of Selected Agricultural Commodities in Sindh Province of Pakistan.

[21] Malik, M. N. (1994) Challenges for the Year 2000 in the Field of Horticulture. Proceedings of the First International Horticulture Seminar. Islamabad: Pakistan Agriculture Research Council.

[22] Organisation, W. H. (2003). FRUIT AND VEGETABLE PROMOTION INITIATIVE.

[23] Ricardo Hausmann, B. K. (2007). Examining Beneficiation .

[24] Swenson, D. (2010). Production in Southwest Iowa Considering Local and Nearby Metropolitan Markets. Leopold Center for Sustainable Agriculture.

[25] Scarborough, V., and J. Kydd (1992) Economic Analysis of Agricultural Marketing: A Manual. Chatham, U.K: Natural Resources Institute. The Pakistan Development Review 35 : 3 (Autumn 1996) pp. $241-255$

[26] Sharif.M.,H.Shah \& W.Akhter (2005) Competitivness of Pakistani fruits in the World Market .

[27] Thane, R. (1997). Processing of fruit and vegetables: effect on carotenoids. Nutrition \& Food Science, 2: 5865.

[28] Visser, S. B. (2012). Capturing the Gains . ISBN : 9781-907247-88-0.

Volume 5 Issue 6, June 2016 www.ijsr.net 